\title{
A MUNKAERŐPIACON ELVÁRT KOMPETENCIÁK RELEVANCIÁJÁNAK ÖSSZEHASONLÍTÓ ELEMZÉSE A MUNKÁLTATÓK ÉS A FELSŐOKTATÁSBAN VÉGZŐS FIATAL MUNKAVÁLLALÓK ASPEKTUSÁBÓL
}

THE COMPARATIVE ANALYSIS OF THE RELEVANCE OF LABOUR MARKET

COMPETENCIES FROM THE ASPECT OF EMPLOYERS AND YOUNG

(UNDER)GRADUATES OF HIGHER EDUCATION

\author{
Varga Erika ${ }^{1}$, Szira Zoltán ${ }^{2}$, Boda Helga ${ }^{3}$, Hajós László ${ }^{4}$ \\ ${ }^{1}$ adjunktus, ${ }^{2}$ egyetemi docens, ${ }^{3}$ nyelvtanár, PhD hallgató, ${ }^{4}$ ny. egyetemi tanár Szent \\ István Egyetem, Gazdaság- és Társadalomtudományi Kar varga.erika@gtk.szie.hu
}

\section{Összefoglalás}

Napjainkra a kompetencia az emberi erőforrás-menedzsment egyik kulcsfontosságú fogalmává nőtte ki magát. Segít eligazodni, hogy milyen tényezők szükségesek ahhoz, hogy a vállalatoknak kiválóan, az átlag felett teljesítő, kompetens dolgozóik legyenek. Tanulmányunkban egyfelöl bemutatjuk, hogy a munkáltatók szerint milyen fö üzleti kompetenciák befolyásol(hat)ják a munkavállalók sikerét és versenyképességét, másfelöl azt, hogy a felsőoktatásban végzős hallgatók szerint mely kompetenciák kulcsfontosságúak a dolgozók kiválasztáskor. További céljaink közt szerepel az összefüggések és az eltérések elemzése, valamint annak vizsgálata, hogy a kompetenciák jelentősége napjainkban nő vagy csökken. A szakirodalmi kutatásra támaszkodva egy olyan kompetencia-struktúrát is tesztelünk, amelyet a magyar munkaerőpiac sajátosságai figyelembe véve állítottunk össze.

\begin{abstract}
Competencies have become one of the key terms of HRM as they help pointing out the factors that are necessary to have excellent employees with outstanding performance over the average. Our paper examines what main business competencies (can) enhance the success and competitiveness of employees from the aspect of employers on the one hand, and what competencies (under)graduate students think will be of vital importance in their selection. It is one of our further objectives to analyse the correlations and point out the possible differences in the opinions of both parties. Our research also examines the role of competencies whether they have been appreciated or depreciated nowadays. Based on literature review, a competence structure tailored to the special features of the Hungairan labour market was also tested.
\end{abstract}

Kulcsszavak: kompetencia, emberi erőforrás-menedzsment, munkaerőpiac, munkáltató, munkavállaló JEL besorolás: R41

LCC: GR865-874

\section{Bevezetés}

A kompetencia az utóbbi évtizedekben az emberi erőforrás-menedzsment egyik kulcsfogalmává vált, hiszen segít annak a kérdésnek a megválaszolásában, hogy mely tényezők szükségesek ahhoz, hogy a munkáltatóknak és a cégeknek kiváló és kompetens dolgozóik (és így hatékony szervezeteik) legyenek, akik (amelyek) az átlag felett teljesítenek.

Cikkünkben ezért egyrészt azt vizsgáljuk, hogy a munkáltatók szerint mely fö üzleti kompetenciák növel(het)ik a kezdő diplomás alkalmazottak sikerét és versenyképességét a munkaerőpiacon, és mely személyiségvonásoknak van döntő hatása az új alkalmazottak felvételénél a döntéshozói mechanizmusra. Másrész azt vizsgáljuk, hogy a felsőoktatásban végzők véleménye szerint milyen 
kompetenciák megléte alapján választják ki a leendő munkaadók a céghez újonnan belépő friss diplomásokat.

Jelenleg ez a kétoldalú vizsgálat - a munkaadók tényleges kompetencia elvárásai és a leendő munkavállalók által prognosztizált kompetenciák - azért is fontos, mert a munkáltatók válogathatnak a közgazdaságtan területén végzett sok frissdiplomás között is. Így számukra kiemelten fontos, hogy őket - saját véleményük alapján - a munkaadók milyen kompetenciák megléte alapján rangsorolják, de azt is fontos tudni, és azzal a munkaeröpiacra belépni készülődő leendő diplomásokat azzal konfrontálni, hogy ez a vélekedés mennyiben találkozik a munkaadók tényleges elvárásaival.

A munkaadók elvárásinak feltérképezése alapján az új dolgozók kiválasztásában jelentős szerepet játszanak azok az elvárt kompetenciák, amelynek megszerzésében jelentős szerepe van a gyakorlati(as) képzésnek. Kutatásunkban többek között arra a kérdésre is kerestük a választ, hogy hogyan értékelődött át és fel, vagy le az egyes kompetenciák szerepe a munkaadók körében, és miként vélekednek a hallgatók a tölük a munkaerőpiacon, mint oda belépőktől elvárt kompetenciákról. További céljaink egyike az volt, hogy a szakirodalom alapján létrehozzunk és teszteljünk egy olyan kompetencia struktúrát, amely a jelenlegi magyar munkaerőpiaci sajátosságokhoz illeszkedik.

\section{Szakirodalmi áttekintés}

„Az Eurostat elörejelzése szerint az EU27 népességének 45,52\%-a lesz 2040-ben 65 év feletti. [...] hiány lesz a magasan kvalifikált munkaerőböl csaknem valamennyi területen. [...] A problémát súlyosbítja, hogy a felsőoktatás általában nem követi a munkaerőpiac szükségleteit és voltaképpen növeli a fiatal diplomások munkanélküliségét.” (Gáthy, 2013; cit: Boda, 2016)

A munkaerőpiacon elvárt kompetenciák megszerzése szempontjából a felsőoktatásban a gyakorlatias képzésnek nagy szerepe lehet, hiszen az elméleti keretekből kilépő, végzett hallgatóktól a cégek már az első naptól gyakorlatias gondolkodást, használható tudást várnak el (Boda, 2016). A munkaerőpiacon elvárt komplex üzleti gondolkodásmód, az integrált, folyamatorientált szemlélet, a vezetői, döntési képességek a gyakorlati oktatás arányának növelésével, abban a cégeknél, azaz a folyó munka területén tartott órák nagyobb számával, továbbá az üzleti szimulációs játékok által is javítható kompetenciák körébe tartoznak. (Boda, 2016)

Az első probléma kapcsán megjegyezzük, hogy a gazdaság periodicitásnak köszönhetően vannak időszakok, amikor egyszerre sok azonos végzettségű ember lép a munkaerőpiacra, így sokan nem a végzettségüknek megfelelő munkakörben kezdenek el dolgozni (Boda, 2016).

A másik problémát az jelenti, hogy a munkaerőpiaci szükségletek és a felsőoktatás által nyújtott kompetenciaportfolió sok esetben - különböző mértékben - eltér. A felsőoktatásban az általános ismereteken túl a készségek, a képességek és a kompetenciák fejlesztése is szükséges ahhoz, hogy a végzés után a munkára való betanulás hatékonyan megtörténjen, és az oktatás világából a munka világába történő átmenet gyors és zökkenőmentes legyen (Kiss, 2010; Boda, 2016).

A felsőoktatásnak alapvetően nem szakmát kell nyújtania a hallgatóknak, hanem szemléletet. A jobb elhelyezkedési esélyeket nyújtó gyakorlatiasság tekintetben pedig már kérdésként merülhet fel, hogy a felsőoktatási szakok kellő mértékben gyakorlatorientáltak-e (Boda, 2016). Kiss és Schmuck (2007) (cit: Boda, 2016) szerint ,a magyar oktatás komoly problémája, hogy ma Magyarországon továbbra is a lexikális tudáson van a hangsúly. A különböző felsőoktatási intézmények vizsgái is lexikai tudást mérnek. Ennek természetesen megvan a maga oka: nagyon nehéz logikai tudást mérni. Bizonyos tantárgyaknál lehet, mint például a matematika, de a legtöbb tantárgynál az mérhető, hogy van egy kötelező tananyag, és azt mennyire sajátították el a 
hallgatók". Korábbi, a V4 országaiban végzett vizsgálataink is a felsőoktatásban a gyakorlatias tudás átadásának a jelenlegi hiányát is igazolták (Hajós és mtsai, 2016)

A kompetencia az emberi erőforrás-menedzsment egyik kulcsfogalmává vált, hiszen segít annak a kérdésnek a megválaszolásában, hogy mely tényezők szükségesek ahhoz, hogy a munkáltatóknak és a cégeknek kiváló és kompetens dolgozóik (és így hatékony szervezeteik) legyenek, akik az átlag felett teljesítenek. A kompetenciára azonban továbbra sem létezik egy egységes meghatározás. Utalnánk arra, hogy például Boyatzis (1982) szerint a kompetencia egy személy olyan tulajdonsága (motivátor személyiségjegy, készség, tudás vagy énkép), amely hatékony és/vagy kiváló munkahelyi teljesítményhez vezet. Ezzel szemben mi a kompetencia fogalmának értelmezése során Spencer és Spencer (1993) következő, széles körben elfogadott definíciójára támaszkodunk: „Alapvető személyes tulajdonságok, amelyek eredményeként adott munkakörben egy munkatárs magatartási alapon értékelhető, előre meghatározott kritériumok szerint jó/kiváló teljesítményt nyújt. (...) A kompetencia az egyén megkülönböztető tulajdonsága, amely oksági kapcsolatban áll egy kritériumhoz kötött hatékony és/vagy jobb teljesítményhez egy munkakör vagy szituáció kapcsán.”

A szervezetek többségénél az új munkatársak kiválasztásának az alapja gyakran a felszíni tudás és készség, miközben az újoncoktól megkülönböztető motivációs és jellemvonás kompetenciákat remélnek, holott ennek ellenkezője sokkal költséghatékonyabb lenne. Igaz ez még a kisvállalkozásokban is, mert még az ott folyó termelés tervezésében is előre meghatározhatóak a szükséges kompetenciák (Magyari - Hajós, 1998).

Az összetettebb intellektuális munkakörökben a kompetenciák szerepe sokkal fontosabb a jobb teljesítmény elöre vetítésében, mint a feladathoz kötött készségek, intelligencia vagy ajánlólevelek, hisz ami a jobban teljesítőket megkülönbözteti, az a motiváció, a személyközi készségek és képességek, amelyek mind kompetenciáknak minősülnek. (Berger - Berger, 2003)

A felsőoktatásban a kompetenciák kialakításában is hatékonyan és gazdaságosan lehet alkalmazni a projektmenedzsment módszert is. (Bitterova és Hajós, 2009) Természetesen azonban a tudás és a szakértelem is számít. Ferencz et al. $(2013,2014)$ vizsgálatai alapján a felsőfokú végzettséggel rendelkezőket alkalmazó cég hatékonyabban müködik. A szerzők publikációja felhívja a figyelmet a menedzsment ismeretek oktatásának a fontosságára a felsőoktatásban. Csehné és Hajós (2014) azt mutatták ki, hogy a képzettebb dolgozók jobban be tudnak illeszkedni a munkahelyükön. Ez igen jelentős és sok oldalról megközelíthető tényező az emberi erőforrás gazdálkodás terén. (Hajós - Berde, 2008)

A munkapiacon ma az tapasztalható, hogy a változások gyorsan követik egymást. Emery (2002) szerint a változásokhoz történő alkalmazkodás és maga a rugalmasság mind kulcsfontosságú elemek a dinamikus és változékony munkahelyi környezetben. A munka és a karrier sikeres menedzselése érdekében tehát fontos a megfelelő erőforrások birtoklása és a karrierkompetenciák megléte (Ulrich et al., 2009). A karrierkompetenciák olyan tudás-, készség- és képességelemek, amelyek központi szerepet töltenek be a karrierfejlesztés szempontjából, és amelyeket az egyén befolyásolhat. (Akkermans et al., 2013)

Napjaink munkahelyei felelősségteljes, öngondoskodó attitüdöt várnak el dolgozóiktól, és arra törekszenek, hogy a dolgozók azonosuljanak a szervezeti értékekkel és célokkal. Roizen és Jepson (1985) rámutattak arra, hogy a munkáltatók kezdeményező-készséggel, problémamegoldó képességgel rendelkező egyéneket vesznek fel, akik értik szervezetüket és a társadalmat, valamint abban aktívan részt is vállalnak. Ferencz és Nótári $(2012,2014)$ szintén megállapították, hogy a szakmai képzésekre kellő hangsúlyt szükséges fektetni. Az oktatási intézményeknek „,...) szoros szakmai kapcsolatot kell kiépítenie a cégekkel és vállalkozásokkal, melyek részben az oktatás gyakorlatorientált követelményrendszerét is képezik". 
A magyar felsőoktatásban tanuló hallgatók munkaerőpiaci elvárások szerinti felkészültségét Czeglédi és Juhász (2013 és 2015) - a munkaadók szemszögéböl végzett vizsgálataik szerint nem találták kielégítőnek. Czeglédi és Juhász (2015) kimutatta, hogy a Visegrádi Négyek országaiban szoros összefüggés mutatható ki az iskolai végzettség és a munkaerőpiacon való érvényesülési lehetőségek között. A munkanélküliség kezelésének nemzetközi és hazai vizsgálata során Gulyás (2001) ugyancsak erre az eredményre jutott, de a magyarországi régiók munkaerőpiaci eltéréseire is rámutatott (Gulyás, 2008).

A felsőfokú képzéssel rendelkezőkön túl is a hazai munkaerő jelenleg estenként, szakmánként és tájegységenként tapasztalt hiányának eseti megoldására, annak bővítését a környező országok magyarul beszélö lakossága is szolgáltathatja (Hajós és Dolmány, 2001).

\section{Anyag és módszertan}

Szakirodalmi kutatásaink alapján feltételezzük, hogy nem célszerü általánosságban beszélni a kompetenciákról, inkább szakmákon, szakmacsoportokon belül adott munkakörre érdemes megvizsgálni az adekvát kompetenciaprofilt, portfóliót. A folyóirat tartalmi és formai elöírásainak terjedelmi korlátozó volta, valamint a kompetenciák óriási elemszáma miatt primer kutatásunk a személyes kompetenciák egy szegmensére és az EU egyik bizottsága által kulcskompetenciaként 2006-ban definiált 8 elemre szorítkozik.

Kompetencia struktúránk azért újszerü, mert jelenleg ilyen összetételben (személyes- és kulcskompetenciák) Magyarországon még nem vizsgálták őket. Kutatásunkkal elöször a megkérdezett munkáltatók oldaláról megközelítve szerettük volna kérdőívünk alapján - amelyből 519 volt értékelhető - feltérképezni azt, hogy manapság a magyar munkaadók a munkavállalók tekintetében milyen kompetencia térképben gondolkodnak.

A primer vizsgálatainkhoz egy, általunk készített standardizált kérdőíveket használtunk. Ezen vizsgálatokból levont tapasztalatok alapján a második - eredményeivel is a következőkben bemutatott - kutatási fázisában a kvantitatív adatfeldolgozás során már egy előtesztelt, véglegesített kompetencia struktúrát elemeztünk.

Az adatok felvételezésekor használt - standartizált - kérdöív összeállításánál törekedtünk valamennyi mérési szinthez (nominális, ordinális, intervallum és arányskála) kérdéseket hozzárendelni, melyek elsősorban zárt kérdések voltak. Figyelembe vettük módszerünk kialakításánál Zéman, Fónagy-Árva és Majoros (2003), továbbá Zéman és Majoros (2010) ez irányú tapasztalatait.

A kvantitatív kutatások eredményeinek feldolgozása során a kérdezettek válaszainak gyakorisági sorrendjét és az említések százalékos arányát számítottuk. Ez után a két csoport - végzős hallgatók és munkáltatók - válaszainak rangsorát vetettük össze, és értékeltük az az azokban talált egyezőségeket és a jelentős eltéréseket.

A vizsgálathoz az 1. táblázatban megadott 33 kompetenciát alkalmaztuk.

\section{Táblázat: Az általunk vizsgált 33 kompetencia felsorolása}

\begin{tabular}{|c|c|c|}
\hline döntésképesség & kommunikációs készség & problémamegoldás \\
\hline együttmüködő észség & körültekintés & rugalmasság \\
\hline elhivatottság, elkötelezettség & meggyőzés & stressztürő képesség \\
\hline EU-s ismeretek & motiválás & szervezőkészség \\
\hline
\end{tabular}




\begin{tabular}{|l|l|l|}
\hline felelősségtudat & megbízhatóság & $\begin{array}{l}\text { szociális érzékenység, } \\
\text { empátia }\end{array}$ \\
\hline gazdasági ismeretek & müszaki ismeretek & szorgalom, igyekezet \\
\hline idegen nyelvi kommunikáció & önállóság & tanulás a hibákból \\
\hline $\begin{array}{l}\text { informatika, számítógépes } \\
\text { ismeretek }\end{array}$ & önfegyelem & tanulási képesség \\
\hline kezdeményezőkészség & önfejlesztés & terhelhetőség \\
\hline kitartás & pontosság & türelmesség \\
\hline kockázatvállalás & precizitás & vállalkozói készségek \\
\hline
\end{tabular}

Forrás: saját szerkesztés

A vizsgált időszakban a munkaadóktól 525 darab kitöltött kérdőív érkezett vissza, melyből végül 519 kérdőív volt értékelhető. Az adatfeldolgozás folyamán azt tapasztaltuk, hogy a faktorszámtól függetlenül bizonyos kompetenciák rendre egy csoportba kerültek, ami arra enged következtetni, hogy ezek a készségek a munkáltatók szerint valamilyen okból kifolyólag összekapcsolódnak, összekötődnek és egy egységet alkotnak.

Ugyanezeket a kompetenciákat használtuk a hallgatói kérdőíveken is, amikor már a hallgatók által a munkaerőpiaci belépéshez prognosztizált kompetencia térképet Varga et al. (2015) módszerével kívántuk megrajzolni. A hallgatóktól ezért azt kérdeztük, hogy szerintük a friss diplomások alkalmazásakor a munkaadók milyen kompetenciákat preferálnak, illetve a megadott kompetenciák jelentősége a közelmúltban csökkent, vagy felértékelödött, illetve változatlan maradt-e.

A vizsgálathoz a hallgatóktól 745 értékelhető kérdőív érkezett vissza.

\section{Eredmények}

A kérdőívek összesítése után kiválasztottuk a munkaadói véleményekből azokat a kompetenciákat - szám szerint a vizsgált 33 kompetenciából kilencet -, amelyeket ők legalább 50\%-ban úgy értékeltek, hogy szerepük az utolsó években megnőtt. Ezen kompetenciáknál a változatlan értékü megítélést is figyelembe vettük, majd az említések arányában sorrendiséget állítottunk fel. Ezen sorrendhez hozzárendeltük az adott kompetenciáknak a hallgatók válaszai alapján kialakult sorrenden elfoglalt helyeit. Így lehetőségünk nyílt összevetésként a hallgatók által legalább 50\%ban említett, de a munkáltatók 50\%-ánál kisebb mértékében minősített kompetenciák kimutatására is.

Mivel az előzőkben említett módszer szerint jelentős eltéréseket is tapasztaltunk, ezért elvégeztük az egymáshoz rendelést a hallgatói sorrend alapján is. Itt 11 olyan kompetenciát regisztráltunk, amelyeket a hallgatók legalább 50\%-ban említettek. Itt is elvégeztük a kompetenciáknak a munkáltatói sorrendben elfoglalt helyének hozzárendelését. Az eredményeket a 2. táblázat szemlélteti. 
2. Táblázat: A kompetenciák munkáltatók szerinti jelentőségének változása az utóbbi öt évben

(az emlitések\%-ában, a hiányzó értékek a jelentőség csökkenésének mértékét jelzik)

\begin{tabular}{|c|c|c|c|c|}
\hline \multirow{2}{*}{$\begin{array}{l}\text { Munkáltatói } \\
\text { rangsor }\end{array}$} & \multirow{2}{*}{ Kompetencia } & \multicolumn{2}{|c|}{$\begin{array}{c}\text { Jelentősége az utóbbi } \\
5 \text { évben }\end{array}$} & \multirow{2}{*}{$\begin{array}{c}\text { Helye a } \\
\text { hallgatói } \\
\text { rangsorban }\end{array}$} \\
\hline & & nőtt & $\begin{array}{c}\text { nem } \\
\text { változott }\end{array}$ & \\
\hline 1. & idegen nyelvi kommunikáció & 71 & 20 & 2. \\
\hline 2. & informatika, számítógépes ismeretek & 69 & 28 & 1. \\
\hline 3. & terhelhetőség & 58 & 26 & 33. \\
\hline 4. & problémamegoldás & 57 & 34 & 9. \\
\hline 5. & tanulási képesség & 52 & 32 & 16. \\
\hline 6. & rugalmasság & 51 & 40 & 29. \\
\hline 7. & önfejlesztés & 51 & 37 & 31. \\
\hline 8. & kommunikációs készség & 50 & 45 & 3. \\
\hline 9. & kitartás & 50 & 34 & 24. \\
\hline \multicolumn{5}{|l|}{$\ldots$} \\
\hline 16. & müszaki ismeretek & 43 & 39 & 6. \\
\hline 17. & meggyőzés & 42 & 45 & 11. \\
\hline \multicolumn{5}{|l|}{$\cdots$} \\
\hline 19. & vállalkozói készségek & 42 & 48 & 10. \\
\hline 20. & tanulás a hibákból & 40 & 53 & 4. \\
\hline \multicolumn{5}{|l|}{$\ldots$} \\
\hline 23. & gazdasági ismeretek & 36 & 53 & 5. \\
\hline 24. & körültekintés & 34 & 53 & 7. \\
\hline \multicolumn{5}{|l|}{$\ldots$} \\
\hline 32. & önfegyelem & 22 & 57 & 8. \\
\hline$\cdots$ & & & & \\
\hline
\end{tabular}

Forrás: saját kutatás $(N=745$, illetve 519)

A válaszadók szerint. - a nem meglepő módon listavezető. - idegen nyelvi kommunikáció és az informatikai ismeretek mellett a személyes értékek közül leginkább a terhelhetőség, a problémamegoldás, a rugalmasság, a tanulási képesség és az önfejlesztés kompetenciák jelentősége értékelődött fel.

A sikeres vállalkozóvá váláshoz - tapasztalataink szerint - további elengedhetetlen kompetenciák (rugalmasság, döntésképesség, körültekintés, kockázatvállalás, kitartás) fejlesztéséről nyilatkoztak úgy a hallgatók, hogy arra leginkább itt lenne arra szükség a felsőoktatásban. 
A megkérdezettek több mint fele az ún. soft kompetenciák közül megemlítette még a hibákból való tanulás, a körültekintés, az önfegyelem, a meggyőzés és a problémamegoldás fontosságát. (A hallgatóknál tapasztalható kommunikációs készség, az idegen nyelv és az informatikai ismeretek jelentősége a munkáltatóknál is megmutatkozott.)

Fontosnak tartjuk arra felhívni a figyelmet arra, hogy a hallgatók nem rendelkeznek megfelelő ismeretekkel a munkaerőpiacon velük szemben támasztott követelményekkel kapcsolatban. Ezt jelzi, hogy a munkaadók által megfogalmazott kilenc olyan követelménnyel szemben, amelyet az utóbbi öt évben nagyobb vagy változatlanul nagy jelentőséggel vesznek figyelembe a leendő munkatársak kiválasztásában, a hallgatók csak négyet (idegen nyelvi kommunikáció, informatika és számítástechnikai ismeretek, problémamegoldás és kommunikációs készség) említenek, ötöt tehát többségüket (terhelhetőség, tanulási képesség, önfejlesztés, rugalmasság, kitartás) - nem kezelik a fontos kompetenciáknak megfelelően.

Különösen problémát jelenthet az, hogy a munkáltatók által a fontossági sorban a 3. helyen említett terhelhetőséget a hallgatók csak a legutolsóként sorolták be, de a 6., 7., 8.-ként a munkáltatók által említett rugalmasságot, önfejlesztést és kitartást is a saját rangsoruk végén említették.

Ha a hallgatók által a munkavállalásnál tölük végzésük után elvárt kompetenciákról alkotott elképzelésük szerint vizsgáljuk azokat, akkor először azt kell említenünk, hogy a hallgatók 11 olyan kompetenciát említettek a vizsgált 33-ból, amelyeknek a munkavállalás során a kiválasztásban betöltött szerepe megnőtt, vagy jelentősége nem változott az utóbbi időben.

Ezeket a kompetenciákat a 3. táblázatban mutatjuk be, amelyben egyben jelöljük, hogy azok a munkáltatói kompetencia-sorrendben hányadik helyen szerepelnek. Ebben a megközelítésben is találtunk lényeges eltéréseket, amelyek a hallgatóknak a munkaerőpiaci kiválasztás feltételeinek nem kellő ismereteire utalnak. Ezt jól jellemzi az, hogy a korábban már említett módon 11 olyan kompetenciát emeltünk ki, amelyröl a hallgatók legalább 50\%-ának az a véleménye, hogy jelentősége a munkaerőpiacon az utóbbi 5 évben megnőtt, de ezzel szemben a munkaadók más kompetenciákat várnak leendő dolgozóiktól. Mivel ez esetben is természetesen kimutathatóvá vált a hallgatók és a munkaadók véleményének eltérése, amelyek közül legnagyobbakat szintén a 3. táblázatban mutatunk be.

A kompetenciák jelentőségének az utóbbi öt évben történt érvelésbeli elmozdulását a két vizsgált csoport, jelentős mértékben eltérően ítélte meg. A válaszadók szerint a nem meglepő módon listavezető idegen nyelvi kommunikáció és az informatikai ismeretek mellett a személyes értékek közül leginkább a kommunikációs készség, a hibákból való tanulás, a gazdasági ismeretek, a müszaki ismeretek, a körültekintés, az önfegyelem a problémamegoldás, a vállalkozói készségek és a meggyőzést jelentősége felértékelődését vélték.

Itt is kimutatható azonban az a jelentősnek ítélhető eltérés a hallgatói és a munkaadói oldal véleménye között. Míg a hallgatók a hibákból való tanulást, a gazdasági és a müszaki ismereteket, a körültekintést, az önfegyelmet és a vállalkozói készségeket jelentős mértékben megnőtt kompetenciának tartják, addig azokat a munkaadók lényegesen alacsonyabb mértékben növekedett kompetenciának jelölték.

Az említetteken kívül a hallgatók még némileg a munkaadóknál nagyobb mértében megnőtt jelentőségünek tartják a meggyőzés kompetenciát.

Az előbb említettekkel szemben itt is több olyan kompetenciát tudtunk kimutatni, amelynek a jelentőségbeli változását a hallgatók a munkaadókkal szemben jelentéktelennek tartják. Ilyen kompetencia például a tanulási képesség, a kitartás, az önfejlesztés és a terhelhetőség. 
Ezt követően a munkáltatókat és a munkavállalókat egyaránt megkérdeztük arról is, hogy az eredményesebb összehangolás érdekében a kompetenciafejlesztésnek milyen formáit javasolják. Az 1. ábra a munkáltatók ebbéli véleményét tükrözi, míg a hallgatók körében végzett felmérésünk eredményét a 2. ábra mutatja be.

\section{Táblázat: A kompetenciák hallgatók szerinti jelentőségének változása az utóbbi öt évben}

(emlitések\%-ban, a hiányzó értékek a jelentöség csökkenésének értékét jelzik)

\begin{tabular}{|c|c|c|c|c|}
\hline \multirow{2}{*}{$\begin{array}{l}\text { Hallgatói } \\
\text { rangsor }\end{array}$} & \multirow{2}{*}{ Kompetencia } & \multicolumn{2}{|c|}{$\begin{array}{c}\text { Jelentősége az utóbbi } \\
5 \text { évben }\end{array}$} & \multirow{2}{*}{$\begin{array}{c}\text { Helye a } \\
\text { munkáltatói } \\
\text { rangsorban }\end{array}$} \\
\hline & & Nőtt & $\begin{array}{c}\text { Nem } \\
\text { változott }\end{array}$ & \\
\hline 1. & informatikai ismeretek & 83 & 1 & 2. \\
\hline 2. & idegen nyelvi kommunikáció & 72 & 8 & 1. \\
\hline 3. & kommunikációs készség & 62 & 5 & 8. \\
\hline 4. & tanulás a hibákból & 60 & 12 & 20. \\
\hline 5. & gazdasági ismeretek & 60 & 6 & 23. \\
\hline 6. & müszaki ismeretek & 57 & 8 & 17. \\
\hline 7. & körültekintés & 55 & 22 & 24. \\
\hline 8. & önfegyelem & 53 & 25 & 32. \\
\hline 9. & problémamegoldás & 51 & 14 & 4. \\
\hline 10. & vállalkozói készségek & 50 & 10 & 19. \\
\hline 11. & meggyőzés & 50 & 8 & 16. \\
\hline$\ldots$ & & & & \\
\hline 16. & tanulási képesség & 47 & 12 & 5. \\
\hline$\ldots$ & & & & \\
\hline 24. & kitartás & 38 & 27 & 9. \\
\hline$\ldots$ & & & & \\
\hline 29. & rugalmasság & 32 & 14 & 6. \\
\hline$\ldots$ & & & & \\
\hline 31. & önfejlesztés & 26 & 14 & 7. \\
\hline$\cdots$ & & & & \\
\hline 33. & terhelhetőség & 21 & 15 & 3. \\
\hline
\end{tabular}

Forrás: saját kutatás $(N=745$, illetve 519)

A munkaadók szerint a változtatásokhoz több szakmai gyakorlatra, kompetencia-fejlesztő tréningekre és speciális tanórákra van szükség. A tréningek szerepére egy korábbi cikkében már Bárdos és munkatársai (2014) is rámutattak. 
A munkáltatók véleményével összhangban a hallgatók is úgy nyilatkoztak, hogy önálló projektfeladatok segítségével tudják leginkább fejleszteni szükségesnek vélt kompetenciájukat. Ez az eredmény is megerősíti, hogy mennyire fontosak és milyen jelentősek azok az önálló, csoportos feladatok, melyeket számos felsőoktatási intézményben igyekeznek integráltan beépíteni az oktatási munkafázisba.

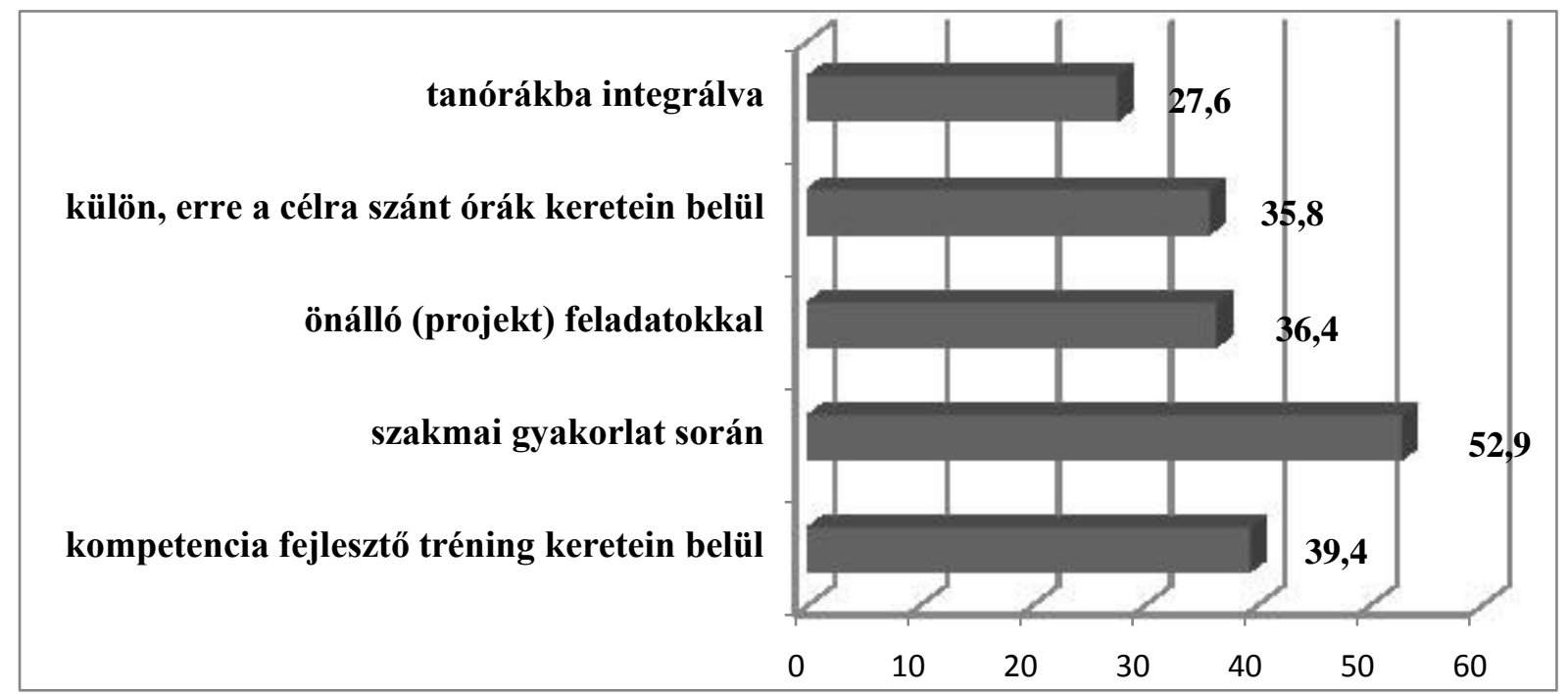

\section{1. Ábra: A kompetenciafejlesztés formáinak megítélése a munkáltatók oldaláról}

(emlitések\%-ban, relativ gyakoriság, több válasz volt adható) Forrás: saját kutatás $(N=745)$

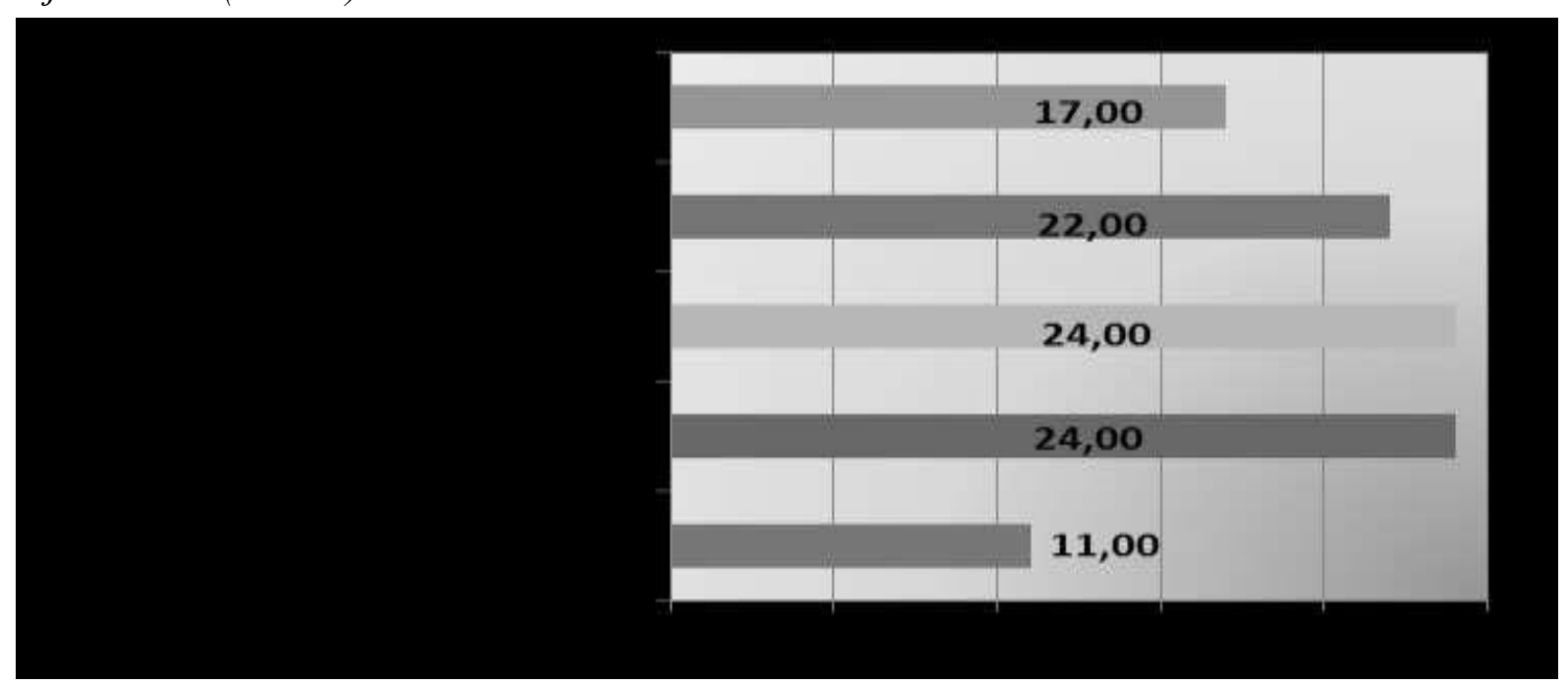

2. Ábra: Kompetenciafejlesztésre vonatkozó hallgatói elképzelések

(\% relatív gyakoriság, több válasz volt adható)

Forrás: saját kutatás $(N=745)$

Vizsgáltuk továbbá azt is, hogy a kompetenciák szerepe a jövőben hogyan alakulhat a megkérdezettek munkaadók szerint. A 3. ábrából jól látható, hogy szerepük felértékelődését 65\%uk prognosztizálja, csökkenésével mindössze 10\%-uk számít. A munkaadók további $25 \%$-a nem vár szerepükben változást.

A munkáltatók közel 2/3-os többsége tehát úgy ítélte meg, hogy a munkahelyen releváns kompetenciák szerepe a jövőben egyre inkább felértékelődik. 


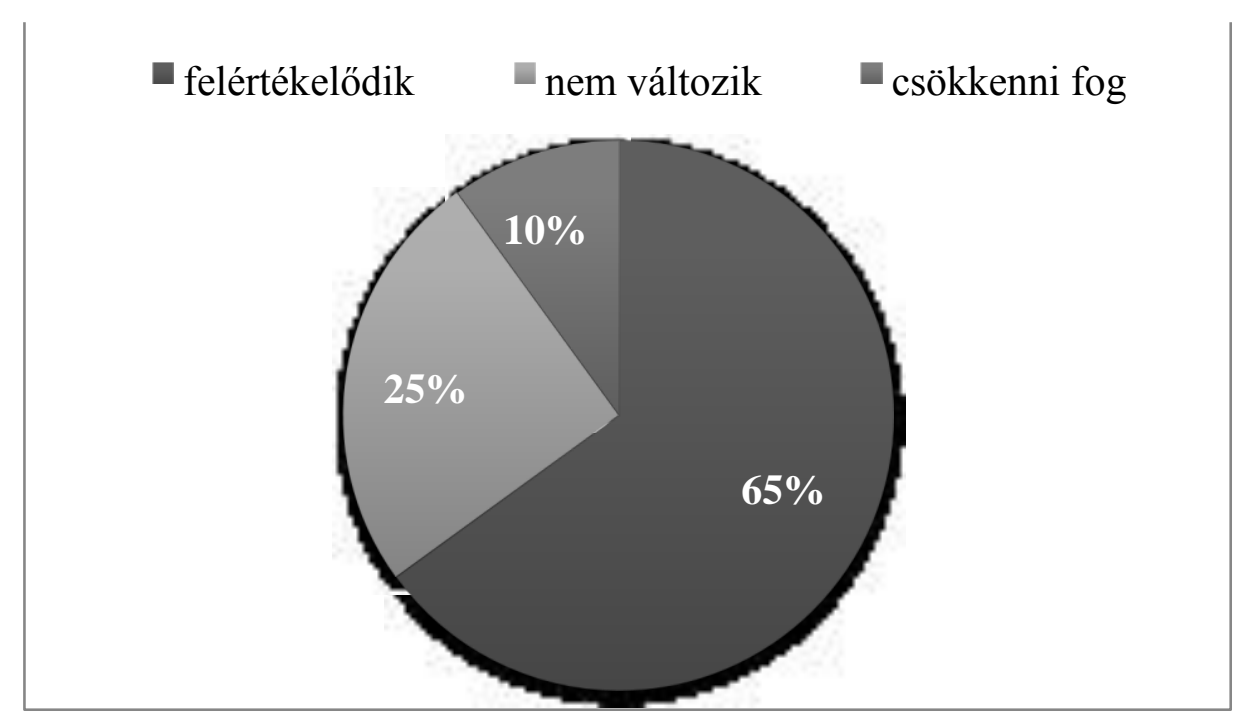

\section{3. Ábra Az általunk vizsgált kompetenciák jövőbeli szerepének megítélése a munkaadók véleménye szerint $(\%)$}

Forrás: saját kutatás $(N=519)$

\section{Következtetések}

A kérdőíveink kiértékelése során megmutatkozott az úgynevezett modern vállalkozói kompetenciák (IKT: kommunikáció, idegen nyelv, számítógépes ismeretek) fontossága, amit felmérésünk alapján a 2. és 3. táblázatban közölt vizsgálati eredményeink jól tükröznek. Az általunk vizsgáltan és megállapítottan kulcskompetenciáknak nevezhető kompetenciák fejlesztésére mind a munkaadók, mind pedig a munkavállalók részéről is igény mutatkozik, ezért ezeknek intenzívebben meg is kellene jelennie az iskolarendszerü felsőoktatásban, sőt azon kívül is. Nagyon fontos a személyes kompetenciák aktualizálása és kellő hangsúlyozása a képzés tartalmi elemei között, amely elősegíti a munkaerőpiac és az oktatás (jobb) harmonizációját.

A munkaerőpiaci elvárások és az oktatás által előnyben részesített kompetenciafejlesztés között esetenként több-kevesebb eltérés ez esetben is tapasztalható volt. Megítélésünk szerint ez a tapasztalat a felsőoktatási kompetenciafejlesztés újragondolásához jól felhasználható, mert az a jelenlegi arányeltolódást jól jelzi, és azt is megmutatja, hogy milyen képességek fejlesztésére kell a felsőoktatásban nagyobb hangsúlyt helyezni a munkaeröpiaci elvárásoknak való jobb megfelelés tükrében.

Az eredményeket látva azonban megfogalmazódott bennünk az is, hogy a megkérdezett munkáltatók nem látják elegendőnek az önfejlesztés fontosságát, ebben inkább az oktatás során várják az előrelépést. A kompetenciafejlesztés módszertanát illetően mind a két fél rámutatott az önálló, projektfeladatok fontosságára.

Vizsgálataink alapján bizonyítást nyert az, hogy a válaszadók többsége a jövőben a kimutatott kulcskompetenciák szerepének további felértékelődésére számít.

Kutatási eredményeink alapján azt is javasoljuk, hogy mivel a kulcskompetenciák gyakorlati ismereteket is feltételeznek, kialakításuk gyakorlati ismeretekhez is kötött, ezért is szükséges az oktatás gyakorlati oldalának további erősítése, és a szakmai és általános készségek és képességek fejlesztése. Ez azon pontok egyike, ahol az oktatás és a munkaerőpiac közötti párbeszéd javítható.

Reményeink szerint a kutatás legfontosabb eredményének valószínüleg az tekinthető, hogy sikerült rávilágítanunk arra, hogy melyek azok a kulcsfontosságú üzleti kompetenciák, amelyek a munkavállalók sikerességét és munkaeröpiaci versenyképességét növelik és növelhetik. Munkánk 
során és alapján egy sajátos kompetenciastruktúra létrehozásával és tesztelésével a személyes kompetenciák átértékelődésére és aktualizálásának szükségességére próbáltuk meg a felsőoktatás szereplőinek a figyelmét felhívni.

\section{Irodalomjegyzék}

1. Fakkermanns, J., Schauferi, W. B., Brenninkmeier, V., Blonk, R. W. B. (2013): The role of career competencies in the Job Demands-Resources Model. Journal of Vocational Behaviour, 83, pp. 356-366. ISSN 0001-8791

2. Bárdos I. K., Varga E., Szira Z., Pallás E. (2014): The significance of trainings and competencies in HR. In: Takácsné György K. (szerk.): Az átalakuló, alkalmazkodó mezőgazdaság és vidék: XIV. Nemzetközi Tudományos Napok: Gyöngyös: Károly Róbert Föiskola, pp. 1547-1557, . ISBN 978-963-9941-75-5

3. Barratt, G. V., Depinet, R. L. (1991): A reconsideration of testing for competence rather than for intelligence. American Psychologist, 46: (10), pp. 1012-1024. ISSN 0003066X, eISSN 1935-990X

4. Berger, L., Berger, D. (2003): The Talent Management Handbook: Creating organizational excellence by identifying, developing, and promoting your best people. Mcgraw-Hill. 466 p. ISBN 978-007-173905-4

5. Bitterova, M., Hajós L. (2009): The School Project Management. Influence on the Economy of Education. Bulletin of the Szent István University Gödöllö. (1) pp. 258 - 262. ISSN 1586-4502

6. Boda, M. A. (2016): A gazdasági diploma munkaerőpiaci helyzete. - Egy lépéssel közelebb a piacképesség felé üzleti szimulációs szoftverekkel. Tantárgyi vizsgadolgozat. Kézirat

7. Boyatzis, R. E (1982): The Competent Manager: A model for effective performance. New York: Wiley. 328 p. ISBN 0-471-09031-X.

8. Csehné Papp I., Hajós L. (2014): Education and working life in Hungary. Acta Tchnica Corviniensis - Bulletin of Engineering, 2: pp. 105-110. e-ISSN 2067-3809

9. Czeglédi Cs., Juhász T. (2013): Role of Tertiary Education in Career and Lifelong Learning Among. The Journal of Education Culture and Society. (01): pp. 190-198. ISSN 2081-1640

10. Czeglédi Cs., Juhász T. (2015): A felsőfokú oktatásban tanulók munkaerő-piaci felkészültsége a munkáltatók szemszögéből. Taylor: Gazdálkodás- és Szervezéstudományi folyóirat. (1-2): pp. 286-293. ISSN 2064-4361

11. Emery, Y. (2002): Added value in HRM: An analysis of the competency management process, Horton-Hondeghem-Farnham. pp. 17-30. ISSN 1382-4414

12. Ferencz Á. Nótári M. (2012): The management of the education and the students in the Kecskemét College. Annals of Faculty of Engineering Hunedoara - International Journal of Engineering. 10:(2) pp. 87-90. ISSN 1584-2665, eISSN 1584-2673:

13. Ferencz Á. Nótári M., Berde Cs. (2013): Management of agrarian education in Hungary. Annals of Faculty of Engineering Hunedoara - International Journal of Engineering 11:(3) pp. 269-272. ISSN: 1584-2665, eISSN: 1584-2673:

14. Ferencz Á. Nótári M. (2014).: Agricultural management in the Hungarian higher education. Lucrari stiintifice: Seria 1 Management 16:(2) pp. 31-36. ISSN 1453-1410 
15. Gáthy V. (2013): Öregedő Európa, fogyó szakemberek - fiatal India, egyre több diplomás. Társadalomkutatás, 31:(1) pp. 40-54. ISSN 0231-2522, eISSN 1588-2918

16. Gulyás L. (2001): A munkanélküliség kezelésének nemzetközi és magyarországi tendenciái. A Pécsi Tudományegyetem Regionális Politika és Gazdaságtan Doktori Iskolájának Évkönyve. 370-388. p. ISBN 978-963-642-271-4, ISSN 1416-0986

17. Gulyás L. (2008): Regional disparities of Hungarian labour market 1990-2005. Forum Geografic. 7(1): pp. 128-135. ISSN 1583-1523

18. Hajós L., Berde Cs., (szerk.) (2008): Emberi erőforrás gazdálkodás. Budapest: Szaktudás Kiadó Ház, 171 p. ISBN 978-963-9732-47-6

19. Hajós L., Dolmány F. (2001) A munkaerő mennyiségi növelésének lehetőségei Magyarországon. Gazdálkodás. XLV: (3) pp. 1-15. ISSN

20. Hajós L., Czeglédi Cs., Marosné Kuna Zs., Szira Z., Varga E. (2016): Felsőoktatásban végzettek vállalkozói szellemének és releváns munkaerőpiaci kompetenciáinak megítélése. Polgári Szemle: Gazdasági és társadalmi folyóirat. 2:(4-6) pp. 263-282 ISSN 1786-6553, eISSN: $1786-8823$

21. Kiss P. (2010): Felsőfokú kompetenciákról nemzetközi kitekintésben. Online elérhetőség: https://www.felvi.hu/pub_bin/dload/DPR/dprfuzet3/Pages17_26_kiss.pdf, [letöltve: 201512-16]

22. Kiss T., Schmuck R. (2007): Szimulációk az oktatásban. A virtuális gazdaságok világa Megjátszott ökonómia, $\quad$ XV. (2) Online elérhetőség: http://feszek.pte.hu/ujsag.php?tipus=cikk\&cikk=1907\&rovat=690\&szam=67\&evfolya $\underline{m=11}$ [letöltve: $2015-12-16]$

23. Magyari J., Hajós L.: (1998): A kisüzemi tevékenységek tervezése. Gazdálkodás. XLII:(4) pp. 52-56. ISSN 0046-5518

24. Roizen, J., Jepson, M. (1985): Degrees for Jobs: Employer Expectations of Higher Education. Guildford: SHRE and NFER-Nelson. 435 p. IBSN 1-85059-005-2

25. Spencer, L. M., Spencer, Jr. S. M. (1993): Competence at Work: Models for Superior Performance. Boston: Wiley, 384 p. ISBN 978-0-471-54809-6

26. Ulrich, D., Allen, J., Brockbank, W., Younger, J. Nyman, M. (2009): HR transformation. Building Human Resources from the Outside. In. New York: McGrawHill. 256 p. ISBN 978-0-071-6387-8

27. Varga E., Czeglédi Cs., Hajós L. (2015): The examination of personal competencies as collateral of success from the point of view of students. Annals of Faculty of Eneneering Hunedoara - International Journal of Engineering. XIII:(4) pp. 117-122. ISSN 15842665, eISSN 1584-2673

28. Zéman Z., Fónagy-Árva P., Majoros Gy. (2003): Értékmérési módszerek alkalmazási lehetőségeinek vizsgálata. Pénzügyi Szemle / Public Financal Quarterly. 8:(4) pp. 380403. ISSN 0031-4960, eISSN 2064-278

29. Zéman Z., Majoros Gy. (2010): Evaluation of the principle. Bulletin of the Szent István University Gödöllö. (1) pp. 348-368. ISSN 1586-4502 